\title{
ANALYSIS AND VISUALISATION OF LAKE DISAPPEARANCE PROCESS IN IŁAWA LAKELAND LANDSCAPE PARK
}

\author{
Weronika Cecylia Marynowska \\ Institute of Geoecology and Geoinformation, Adam Mickiewicz University in Poznań, Poland
}

Manuscript received: January 5, 2018

Revised version: February 28, 2018

\begin{abstract}
MARYNOWSKA W., 2018. Analysis and visualisation of lake disappearance process in Iława Lakeland Landscape Park. Quaestiones Geographicae 37(1), Bogucki Wydawnictwo Naukowe, Poznań, pp. 115-124, 5 figs, 3 tables.

AвSTRACT: Lake disappearance as a natural stage of evolution of lakes is an extremely important issue in the landscape and ecosystem research context. Studies of the changes that occur in the lake landscape, characteristic in the northern part of Poland, are aimed at defining the cause and forecasting the results. The possibilities of the Geographic Information Systems (GIS) were used in this paper to analyse and visualise the process of lake disappearance in the Iława Lakeland Landscape Park. GIS technologies which primarily are used for gathering, storing, processing and presenting spatial data have been used to interpret changes in lakes coverage over a period of 100 years. The analysis were based on data bases and cartographic former maps such as hydrographic maps, attribute data and bathymetric plans. The data was gathered by transfer from different geoportals, next vectorised, and then preprocessed. Former maps were rectified. The lake disappearance process was presented in several forms: lake cards, animations and interactive map. Basing on the GIS analysis about lake disappearance in Iława Lakeland Landscape Park it was possible to state that lakes are disappearing in rate of $3.99 \mathrm{ha} \mathrm{a}^{-1}$.
\end{abstract}

KEY wORDS: lake disappearance, Geographic Information Systems (GIS), spatial analysis, Ilawa Lakeland Landscape Park Corresponding author: weronika.marynowska@amu.edu.pl

\section{Introduction}

Lake evolution process in Poland is a topic often undertaken in various studies which indicates the importance of this issue (KleczewskaWitt 1983, Kowalczyk 1993, Choiński 1996, 2001, 2002, 2006, Choiński, Ptak 2008, Jańczak 1997, Nowacka, Ptak 2007, Ptak 2010, 2013a, b, Grandke 2009, Urbański, Kryla-Staszewska 2009, Piasecki 2013, Krąż, Piasecki 2015). What the aforementioned studies have in common, is the conclusion that the process accelerates and the total disappearance of many lakes in the next few decades is possible. These tendencies are most clearly visible in the lakes within the lower-glacial area of the Polish Lowlands (Kalinowska 1961). In a temperate humid climate, distinctive for Poland, the lake disappearance process gradually leads to the formation of swamps and peat bogs. The literature distinguishes two main factors related to lake evolution that occur either simultaneously or separately (Choiński 1988, Jańczak 1997):

- variability of the lake water level, related to climate change and anthropogenic and natural changes in the catchment areas (such as deforestation, land improvement, migration, urbanization),

- accretion of the bottom sediments in lakes, occurring through the growth of the biogenic mass, precipitation of chemical compounds, sedimentation of mineral matter and deposition of aeolian particles. 
The rate of overgrowing processes related to lake evolution varies according to morphometry of lakes, land use and land cover types in the catchment and also climatic and hydrological conditions (Ptak 2013a). Human activity such as land improvement and regulations in river and lake systems has also significant impact. However, regardless of the reasons for the disappearance of lakes, it can be regarded as an inevitable process that will lead to a total disappearance of most lakes in Poland in the next two thousand years (Choiński 1995).

Due to the constant increase of the rate of lake disappearance and the general acceleration of changes occurring in the environment, caused by human activity and climate change, there is a need for more effective gathering and analysis of spatial big data. The paper pays attention to geoinformation methods of data acquisition, storage and processing, as well as advanced spatial data visualisation techniques that enables the presentation of spatial and nonspatial data for lake disappearance in postglacial area of Polish
Lowland. The aim of the study is to assess qualitatively and quantitatively the lake disappearance process in the Iława Lakeland Landscape Park. The geographic information systems (GIS) were used to determine the tendencies and rate of lake changes and to visualise these changes.

\section{Study area}

The analysis of lake disappearance and spatial data presentation were carried for lakes located in the Iława Lakeland Landscape Park and the buffer zone of the park (Fig. 1). The total area of the analysed region is 38923.6 ha. Iława Lakeland Landscape Park is located in the South Baltic Lakeland in the north-east Poland.

There are 43 lakes in the Park and its buffer zone and the lake density is about $14.5 \%$. The biggest lake in this region is Lake Jeziorak, which is the sixth largest (area $3460 \mathrm{ha}$ ) and the first longest $(27.5 \mathrm{~km})$ lake in Poland. There are eight lakes in the Iława Lakeland Landscape Park with the

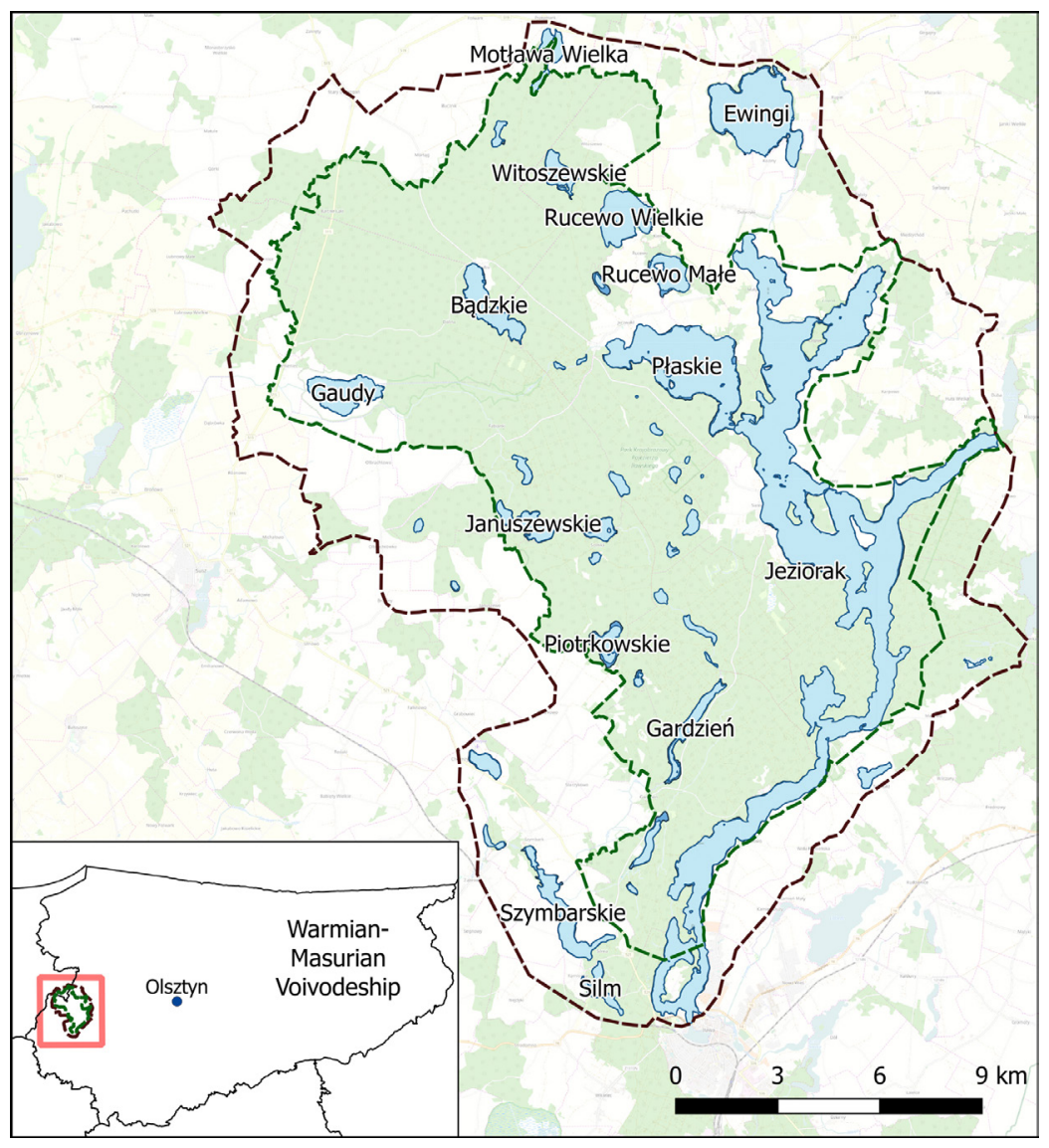

Fig. 1. Location of lakes in Iława Lakeland Landscape Park. 
area exceeding 100 ha. All of the analysed lakes are trough lakes (e.g. Jeziorak, Bądzkie), moraine lakes (e.g. Ewingi, Gaudy) and kettle-hole lakes (e.g. Łabędzie, Parkun). Their age is geologically short and their disappearance is a natural stage of evolution (Choiński 1988). The lakes of Iława Lakeland Landscape Park were formed during the last Vistulian (Weichselian) glaciation so the youngest lakes are about 15000 years old (Dobies, Planter 1998). In addition, many lakes of the Iława Lakeland Landscape Park are flowthrough lakes (e.g. Łabędzie, Osa, Siemiańskie), which additionally affects the rate of lake shape changes and their shallowing.

\section{Data sources and research methods}

In order to analyse the rate of lake disappearance in the Park, a number of methods were used in the subsequent stages (Fig. 2). The key stage in the analysis of lake disappearance was to prepare a set of spatial data that would best reflect the changes taking place in the lakes, assuming the cartographic comparability of source materials. For this purpose, the following cartographic materials were collected:

- Die Karte des Deutschen Reiches - scale 1:100 000, 1893: Christburg (Dzierzgon), Deutsch-Eylau (Iława) (KDR 1893),

- Topographische Karte (Messtischblatt-Ostdeutschland) - scale 1:25 000, 1928: 2182 Alt Christburg (Stary Dzieżgoń), 2183 Saalfeld (Zalewo), 2282 Rosenberg in Westprussen (Prabuty i Różnowo), 2283 Schwalgendorf (Siemiany), 2284 Schnellwalde (Boręczno), 2382 Sommerau (Ząbrowo), 2383 Tillwalde (Tynwałd), 2384 Bergfriede (Samborowo) (Mapster 2017),

- Topographic map in 1965 coordinate systemscale 1:25 000: 221.24 Zalewo, 221.41 Prabuty, 221.42 Jerzwałd, 222.31 Miłomłyn, 221.44 Siemiany, 222.33 Samborowo, 231.22 Iława (GUGiK 1982),

- Hydrographic map - scale 1:50 000: N-34-76-A Zalewo (2007), N-34-75-D Susz (2008), N-3476-C Jerzwałd (2010), N-34-87-B Kisielice (GGK 2001), and N-34-87-A Iława (GGK 2010)

- Orthophotomap - resolution 0.5 m (GGK 2014). There are significant differences between all used maps, resulting from the mapping and

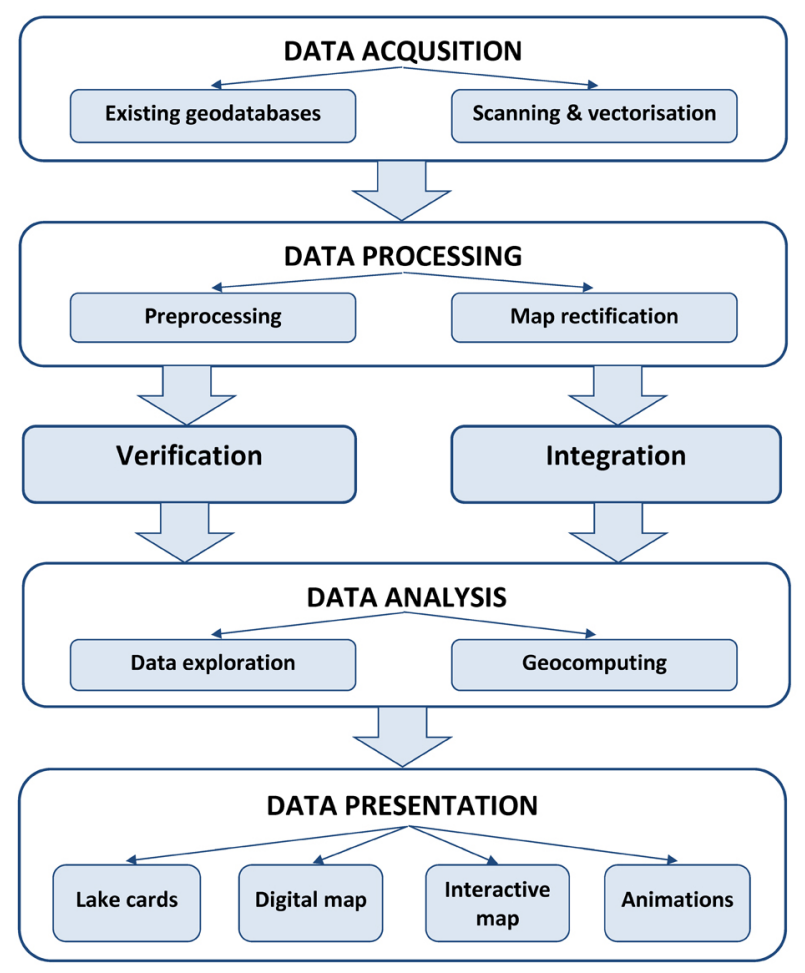

Fig. 2. Workflow chart for geoinformation analysis of lake disappearance.

publication period and also different methods of data processing. Therefore, it was necessary to preprocess the input data (especially former German maps) before the main analysis. All inaccuracies resulting from scanning former analog maps were eliminated, all maps were rectified, vectored, verified and then integrated into the database. All stages of the work are presented on the workflow chart (Fig. 2).

The next stage of the lake disappearance analysis were calculations carried out on the integrated dataset that included identification of differences between each periods and statistical data analysis to define the tendency and rate of lake disappearance process.

The last stage of the analysis was visualisation of spatial data. It is essential for determining characteristics of changes of inside the lake systems. The results of conducted research was visualised through cards of lakes prepared for all lakes with area greater than 15 ha. The exemplary card, prepared for Ewingi Lake is presented on Fig. 3. The card constitute a comprehensive summary of information about lake that includes information about the area, length of shoreline, average and maximum depth and degree of changes in period of over 120 years. 

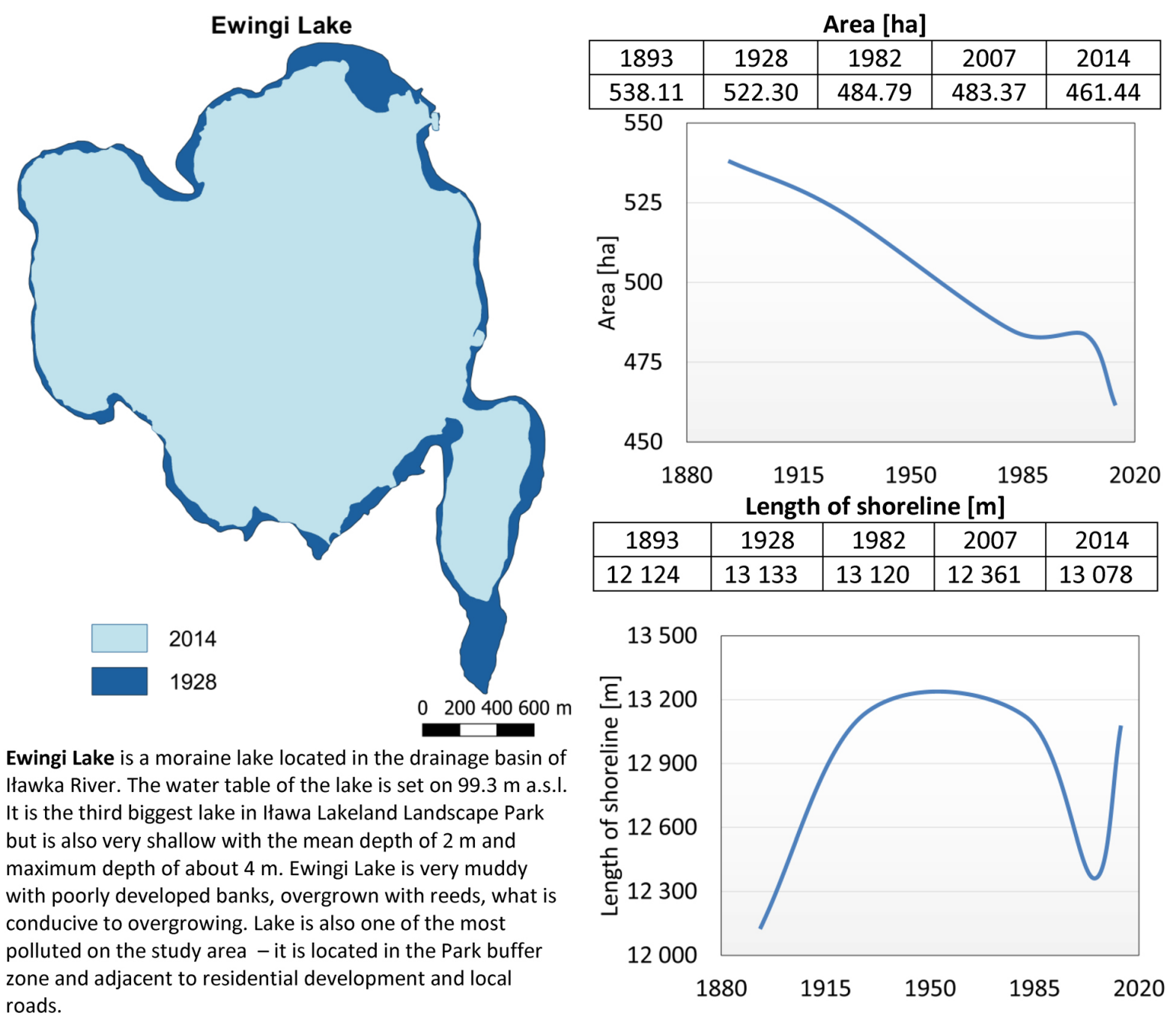

Fig. 3. Document card of Ewingi Lake.

Moreover, digital and interactive methods of spatial data presentation were used, such as animations published in GIF format and an interactive map prepared and published via the Internet on the ArcGIS Online. All visualisation methods, as a result of analysis, present the lake disappearance process in a comprehensive way.

\section{Results}

Geoinformation analysis and geocomputation, carried out within this research, allowed to characterise the lake disappearance process in the Iława Lakeland Landscape Park. The comparison of total area of the Iława Lakeland Landscape Park with total area of the lakes enabled to determine the changes in the lake area. To describe the changes in the lakes area, data from five time spans for each lake are presented in Table 1.

Compared data, gathered in Table 1 was the basis for calculation of another parameter, used to describe the general tendencies of the lake disappearance process. The information about total area of lakes and lake density of each period were presented in Table 2.

According to this data, it might be assumed that between 1893 to 2014 the general tendency points to decrease of total area of lakes in the Iława Lakeland Landscape Park by 482.91 ha which is $8 \%$ of total lake area. Similarly, conducted calculations enabled to determine that lake density of the Landscape Park in the first period in 1893 was $15.57 \%$ and in following 121 years decreased by $1.24 \%$ to $14.33 \%$ in 2014 . The rate of the changes, calculated as the quotient 
of decreased area and the number of years be-

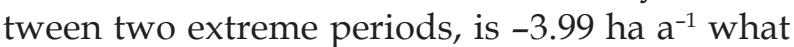
indicates a decrease of the total lake area for almost 4 ha each year. Regardless of general conclusion, there is a deviation between 1982 and
2007 where both values presented in Table 2 increased. Increase of the total lake area is related to appearance of three Gutlinek lakes that are periodic lakes with their disappearance between 2000 and 2014.

Table 1. Area and length of shoreline for chosen lakes of the Iława Lakeland Landscape Park.

\begin{tabular}{|c|c|c|c|c|c|c|c|c|c|c|}
\hline \multirow{2}{*}{ Lake name (PRNG*) } & \multicolumn{5}{|c|}{ Area [ha] } & \multicolumn{5}{|c|}{ Length of shoreline [m] } \\
\hline & 1893 & 1928 & 1982 & 2007 & 2014 & 1893 & 1928 & 1982 & 2007 & 2014 \\
\hline Bądzkie & 153.81 & 153.49 & 144.15 & 141.80 & 133.98 & 8457.9 & 8601.9 & 8006.5 & 7755.3 & 8143.3 \\
\hline Czarne & 2.38 & 2.12 & 0.48 & 0.56 & 0.56 & 710.7 & 726.7 & 258.2 & 280.9 & 281.0 \\
\hline Czerwica & 50.45 & 51.02 & 38.35 & 39.47 & 34.54 & 4642.6 & 4830.6 & 4359.5 & 4342.5 & 4216.7 \\
\hline Ewingi & 538.11 & 522.30 & 484.79 & 483.37 & 461.44 & 12124.0 & 13133.0 & 13120.0 & 12361.0 & 13078.0 \\
\hline Gardzień & 82.52 & 79.87 & 83.10 & 79.12 & 69.35 & 9643.5 & 9006.9 & 8307.3 & 8231.7 & 8383.5 \\
\hline Gaudy & 189.73 & 160.52 & 160.30 & 159.45 & 158.12 & 6614.6 & 6114.4 & 6504.5 & 6273.5 & 6628.8 \\
\hline Gębin & 22.97 & 17.21 & 16.19 & 15.28 & 15.54 & 3113.4 & 2325.6 & 2644.1 & 2155.1 & 2272.4 \\
\hline Gieźniary & 11.25 & 10.26 & 10.56 & 11.07 & 10.27 & 1313.4 & 1261.0 & 1306.2 & 1304.6 & 1265.2 \\
\hline Głębokie & 9.47 & 9.04 & 7.87 & 7.98 & 7.49 & 1323.9 & 1265.1 & 1139.9 & 1135.0 & 1147.4 \\
\hline Gutlinek Mały & nd & nd & nd & 1.18 & 0.66 & nd & nd & nd & 441.5 & 419.6 \\
\hline Gutlinek Średni & nd & nd & nd & 7.62 & 0.00 & nd & nd & nd & 3164.1 & 0.0 \\
\hline Gutlinek Wielki & nd & nd & nd & 23.85 & 5.79 & nd & nd & nd & 2838.8 & 1926.1 \\
\hline Januszewskie & 118.28 & 113.27 & 96.87 & 97.90 & 87.95 & 7373.1 & 7695.2 & 7512.3 & 7366.7 & 7297.4 \\
\hline Jeziorak & 3144.17 & 3222.56 & 3171.25 & 3187.84 & 3107.11 & 118056.9 & 123864 & 124926.6 & 121788.8 & 128476.2 \\
\hline Kawka & 20.55 & 24.44 & 22.39 & 21.54 & 21.32 & 2619.3 & 2658.6 & 2606.2 & 2480.5 & 2605.5 \\
\hline Kociołek Wielki & 7.56 & 8.02 & 7.43 & 8.03 & 7.41 & 1067.8 & 1117.6 & 1128.8 & 1151.2 & 1117.4 \\
\hline Kołm & 39.71 & 40.97 & 41.68 & 41.66 & 38.99 & 2813.1 & 2887.7 & 2905.0 & 2925.4 & 3058.9 \\
\hline Leśne & 0.00 & 5.97 & 5.42 & 4.98 & 4.26 & - & 912.3 & 888.5 & 841.5 & 811.3 \\
\hline Lute & 3.44 & 3.13 & 2.06 & 2.09 & 2.09 & 793.2 & 723.1 & 568.2 & 573.0 & 573.0 \\
\hline Łabędzie & 30.58 & 24.24 & 22.16 & 23.23 & 22.10 & 2637.1 & 2163.1 & 2086.9 & 2091.0 & 2082.7 \\
\hline Mały Gardzień & 5.96 & 4.07 & 3.31 & 4.02 & 3.16 & 1504.6 & 1378.9 & 1252.7 & 1313.8 & 1355.8 \\
\hline Motława Wielka i Mała & 55.40 & 50.17 & 54.30 & 52.57 & 53.52 & 6857.1 & 6778.6 & 6837.7 & 6670.5 & 6907.9 \\
\hline Olszewo & 15.85 & 9.16 & 7.76 & 8.44 & 8.01 & 1518.5 & 1092.8 & 1096.2 & 1097.4 & 1191.6 \\
\hline Osa & 19.42 & 21.96 & 20.27 & 21.49 & 20.60 & 3357.3 & 2934.5 & 2973.8 & 2940.3 & 2948.9 \\
\hline Parkun & 10.80 & 11.53 & 11.13 & 12.13 & 12.04 & 1312.3 & 1339.8 & 1315.0 & 1373.4 & 1379.7 \\
\hline Piotrkowskie & 93.49 & 72.70 & 67.38 & 59.99 & 48.96 & 5754.4 & 4454.0 & 4354.3 & 3828.7 & 3858.9 \\
\hline Piotrówka & 36.31 & 28.32 & 9.45 & 15.48 & 6.76 & 2734.3 & 2466.4 & 1308.9 & 1717.0 & 1447.4 \\
\hline Płajteczek & 4.25 & 4.32 & 3.52 & 3.59 & 3.31 & 804.7 & 814.2 & 741.7 & 720.7 & 704.5 \\
\hline Płajtek & 7.69 & 8.77 & 7.94 & 7.99 & 7.46 & 1642.0 & 1675.9 & 1681.2 & 1719.1 & 1629.5 \\
\hline Płaskie & 617.54 & 634.65 & 611.84 & 614.32 & 582.20 & 17527.7 & 18029.8 & 17855.0 & 17694.1 & 19211.9 \\
\hline Rucewo Małe & 111.05 & 103.72 & 94.56 & 97.15 & 88.44 & 4712.1 & 5418.7 & 5213.5 & 5006.3 & 4913.8 \\
\hline Rucewo Wielkie & 220.52 & 191.11 & 177.36 & 185.69 & 177.46 & 9889.3 & 6683.0 & 6766.6 & 6456.0 & 6615.7 \\
\hline Siemiańskie & 23.10 & 22.80 & 22.07 & 23.10 & 22.43 & 2200.4 & 2128.4 & 2084.7 & 2129.5 & 2104.3 \\
\hline Silm & 50.93 & 54.38 & 51.03 & 52.50 & 50.25 & 5091.6 & 5423.7 & 5167.6 & 5293.7 & 5280.0 \\
\hline Stęgwica & 50.06 & 44.32 & 42.29 & 38.36 & 32.31 & 5068.0 & 4786.2 & 4569.9 & 4291.1 & 3494.3 \\
\hline Szymbarskie & 164.37 & 167.28 & 153.42 & 154.47 & 144.93 & 11977.2 & 12056.2 & 11959.0 & 11780.0 & 11426.5 \\
\hline Twarożek & 6.58 & 6.47 & 3.16 & 3.86 & 3.19 & 1177.0 & 1204.3 & 971.1 & 1067.7 & 950.0 \\
\hline Twaruszek & 5.81 & 6.60 & 5.33 & 5.90 & 4.82 & 1424.4 & 1273.0 & 1036.7 & 1073.5 & 948.2 \\
\hline Tynwałdzkie & 29.24 & 31.47 & 31.75 & 31.90 & 30.82 & 2931.7 & 3128.2 & 3067.2 & 3130.0 & 3084.1 \\
\hline Witoszewskie & 78.93 & 64.34 & 68.45 & 67.61 & 64.93 & 4092.4 & 4885.9 & 5075.2 & 4962.6 & 4824.2 \\
\hline Ząbrowskie & 17.32 & 16.65 & 13.21 & 14.46 & 12.88 & 2465.7 & 2545.6 & 2414.3 & 2508.6 & 2399.7 \\
\hline Zdryńskie & 5.02 & 5.37 & 4.04 & 5.42 & 3.68 & 1014.3 & 1073.1 & 917.9 & 1670.4 & 999.5 \\
\hline
\end{tabular}

* PRNG - Państwowy Rejestr Nazwa Geograficznych (National Register of Geographical Names); nd - no data.

Table 2. Lake area and density for total data of the Iława Lakeland Landscape Park.

\begin{tabular}{|l|c|c|c|c|c|}
\hline \multicolumn{1}{|c|}{ Period } & 1893 & 1928 & 1982 & 2007 & 2014 \\
\hline Area [ha] & 6060.32 & 6008.55 & 5795.00 & 5818.43 & 5577.41 \\
\hline Lake density [\%] & 15.57 & 15.44 & 14.89 & 14.95 & 14.33 \\
\hline
\end{tabular}



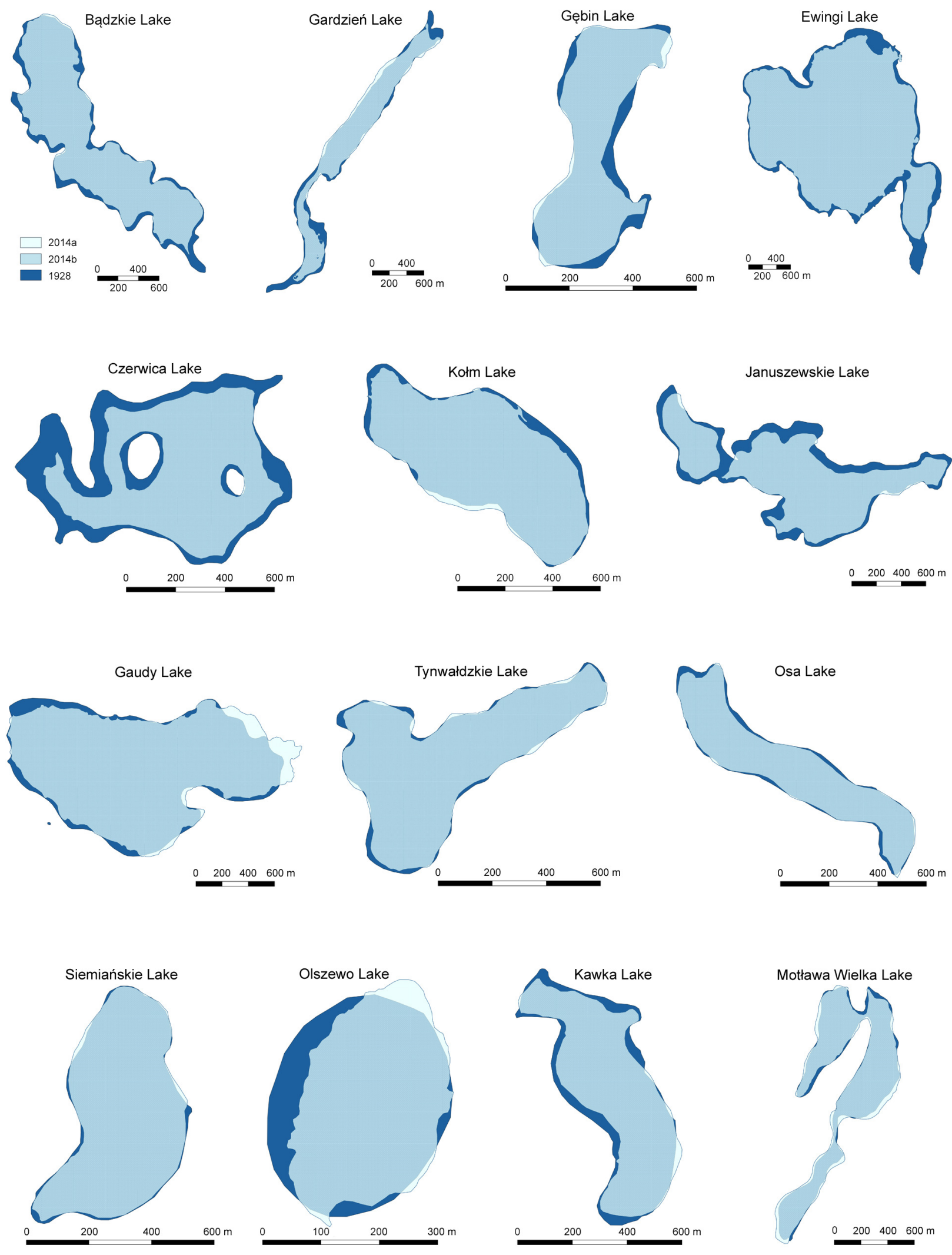

Fig. 4. Set of lake maps show the places, ways and rates of lake disappearance in years 1928 and 2014 (a - land area occupied by the lake in 2014, b - lake range in 2014 in the lake border from 1928) for selected lakes in the Iława Lakeland Landscape Park. 

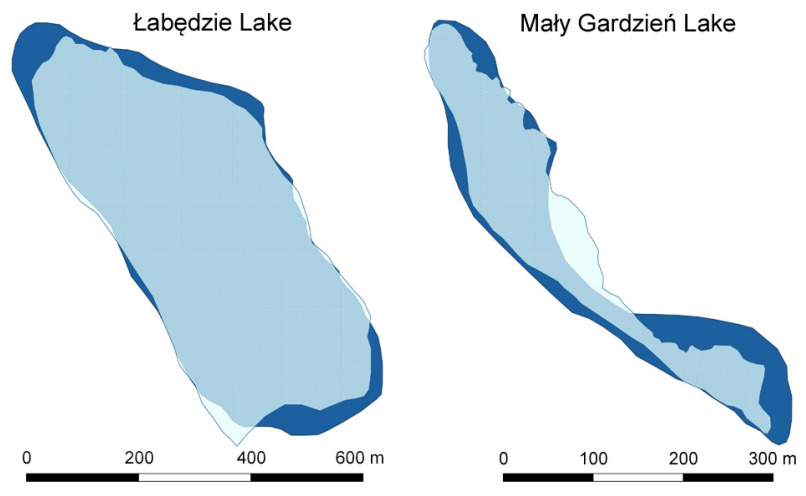

Jeziorak Lake
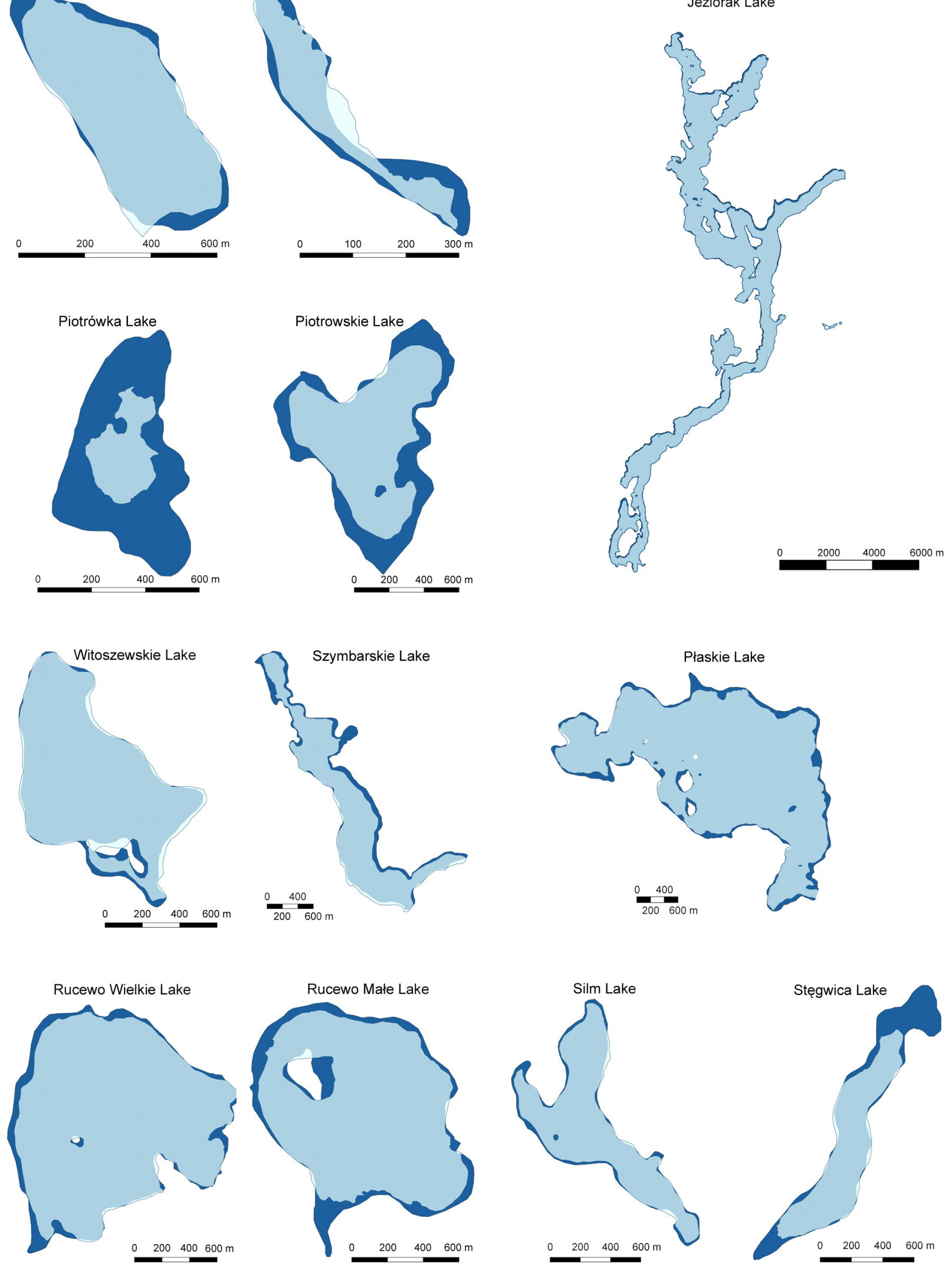

Fig. 4. cont. 
Table 3. Lake area and density changes for total data of the Iława Lakeland Landscape Park.

\begin{tabular}{|l|c|c|c|c|c|}
\hline \multicolumn{1}{|c|}{ Time span } & $1893-1928$ & $1928-1982$ & $1982-2007$ & $2007-2014$ & $1893-2014$ \\
\hline Period [years] & 35 & 54 & 25 & 7 & 121 \\
\hline Lake area change [ha] & -51.76 & -213.56 & 23.43 & -241.02 & -482.91 \\
\hline Rate of lake area change [ha] & -1.48 & -3.95 & 0.94 & -34.43 & -3.99 \\
\hline Lake density change [\%] & -0.13 & -0.55 & 0.06 & -0.62 & -1.24 \\
\hline
\end{tabular}

Information about changes between each period was calculated and presented in Table 3. All values confirm the statement above, the main tendency that lakes disappear constantly with a deviation between 1982 and 2007. The largest change in the area of lakes was calculated for 2007-2014. This is a characteristic feature for such a short period of time, i.e. 7 years. In case of longer observation periods ( 25 and 35 years) the rate of lake disappearance drops significantly. Hence, it is possible to recommend a longer time span to determine the rate at which lakes disappear.

An important part of the research was also to present the results of lake disappearance process with the usage of GIS tools. Modern geovisualisation methods allow to present the changes in environment that appears constantly in time but first of all enable the visualisation of the direction of changes in each lake. A set of maps for each lake that show the changes between 1928 and 2014 is presented on Fig. 4. Thanks to these lake maps it is clearly noticeable that lake disappearance is not a regular process and the general tendency for a lake basin does not show variability across the entire shoreline. It should be emphasised that the process of lake disappearance concerns lakes of various types, with different origins and areas. The largest decrease of the lake area occurred in the group of small and very small lakes, however the lake disappearance process tendency has been consistently maintained over the last 100 years on all analysed lakes. The review of the differential maps for individual lakes does not allow a detailed qualitative characterisation of their disappearance process. This process is heterogeneous, there are no privileged places for this process, local variability of disappearance is varied and depends on many factors, such as the lithological type of the coastal zone, land cover and land use type, water pollution and human impact on the coastal zone.

Information about lake area, density and location were used to prepare an interactive online map that is an integral part of the analysis. The interface of the map is presented on Fig. 5. The map was prepared and published on the

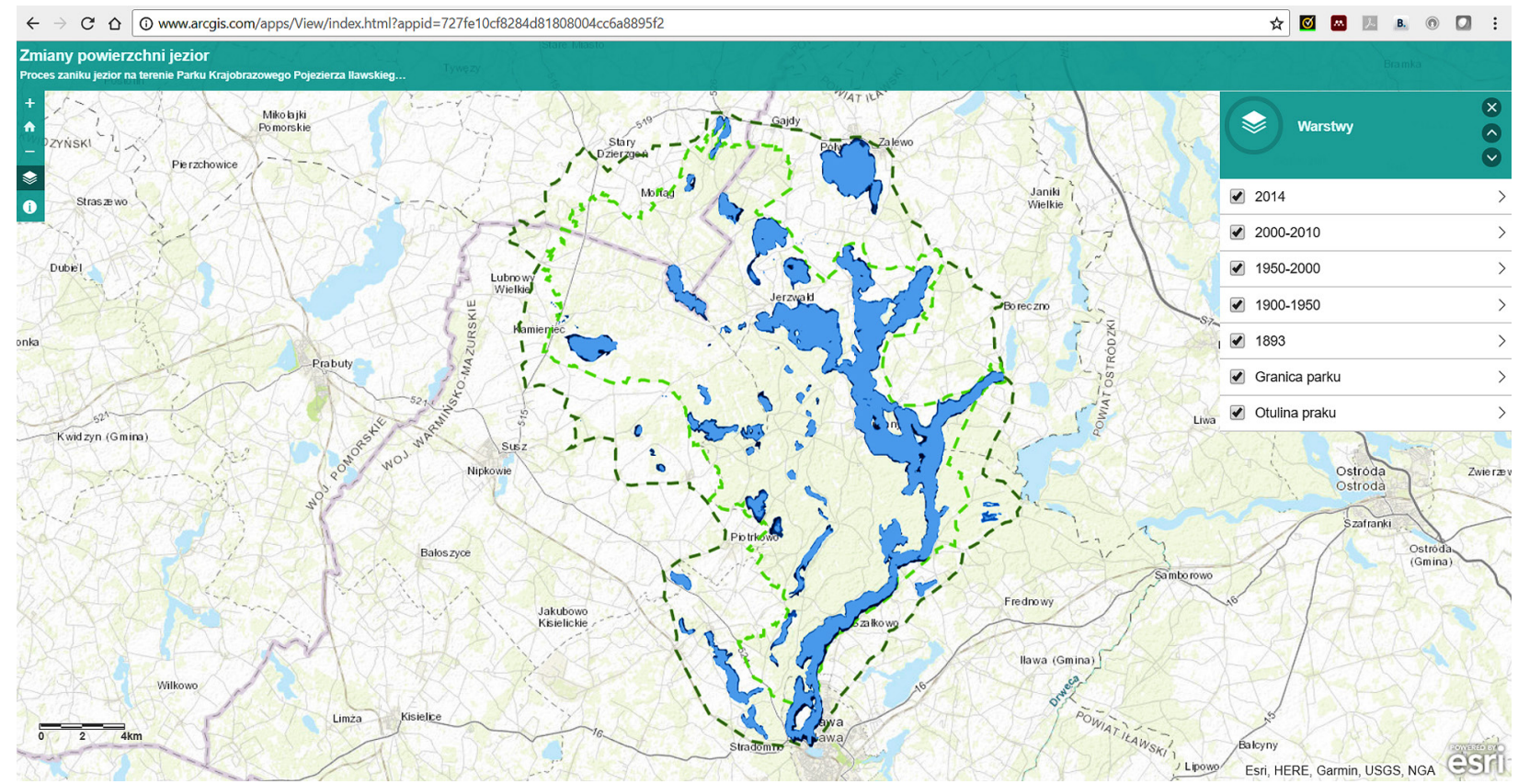

Fig. 5. Interactive map interface on the server of ArcGIS Online. 
ArcGIS.com platform that provides an extensive set of editing and analytical tools for thematic map preparation. The platform is distributed by Environmental Systems Research Institute. The map interface includes two functions of zoom in and zoom out of the map, return to the general view of the entire lakeland, the choice of layers to the lake extent from particular years, and a window with brief information on the map. Thanks to the free choice of layers for different years, it can track different rates of disappearance of individual lakes. Clicking on the lake it can read its name, area and length of the shoreline. Publishing the map online enables the interaction with the content of the map. These interactive map functions are in accordance with the recommendations for this kind of maps given by Macioch and Malmon (2010).

\section{Conclusions}

The lakes of Iława Lakeland Landscape Park have been disappearing constantly in the last 121 years. The area of lakes in Iława Lake District Landscape Park between 1893 to 2014 decreased by 482.9 ha, which correspond to the rate of the lake area changes equal to almost 4 ha each year. No pattern was observed in the disappearance of lakes. Each of these lakes has its own way of disappearing and at the same time overgrowing. Due to slow disappearance of lakes, new waterbodies emerged (e.g. due to the division of the Lake Januszewskie), new lake islands were created (especially on the Jeziorak lake) and the area of the current islands was enlarged (e.g. on Lake Czerwica).

The results of the work are in accordance with the results of the similar studies. The studies conducted in different regions in Poland stated the conclusion that lake area changed in $0.23 \%$ per year in Sławskie Lakeland (Grandtke 2009), 0.11\% per year in Dobrzyńskie Lakeland (Piasecki 2013) and $0.18 \%$ per year in Żnin Region (Ptak 2013b). The rate of changes also accelerates in last 30 years (Piasecki 2013). In this research conducted for Iława Lakeland Landscape Park, changes in lake area varied between $0.037 \%$ and $0.1 \%$ per year what is convergent with other calculated values. The aforementioned papers and the results of this study allow to state that significant changes in the surface of lakes in the area of the lakeland appeared and the changes are constantly accelerating over the years.

The analysis of spatial data from over 120 years allowed to record the rate of changes in the lakes $\left(4 \mathrm{ha} \mathrm{a}^{-1}\right)$ and to describe a scenario that might happen in the Iława Landscape Park. Intensive tourist activity, land use and land cover transformations, as well as climatic changes have contributed to significant changes in the landscape of the Iława Lakeland Landscape Park.

\section{Acknowledgements}

The author would like to thank to Prof. UAM Dr. hab. Renata Graf for valuable suggestions and support during the research work and preliminary version of manuscript.

\section{References}

Choiński A., 1988. Wybrane zagadnienia z limnologii fizycznej Polski. Wydawnictwo Naukowe UAM, Poznań.

Choiński A., 1995. Modern tendencies of changes in the surface of lakes in Poland. Quaestiones Geographicae 17-18: 5-12.

Choiński A., 1996. Katalog jezior Polski. Wydawnictwo Naukowe. UAM, Poznań.

Choiński A., 2001. Katalog jezior Polski. Wydawnictwo Naukowe UAM, Poznań.

Choiński A., 2002. Przykłady współczesnego zaniku jezior $\mathrm{w}$ Polsce. Obieg wody w zmieniajacym się środowisku. Prace Instytutu Geografii AŚ w Kielcach 7: 247-258.

Choiński A., 2006. Katalog jezior Polski. Wydawnictwo Naukowe UAM, Poznań.

Choiński A., Ptak M., 2008. Zanikanie jezior w Wielkopolsce na tle Polski. Roczniki gleboznawcze 59(2): 25-31.

Dobies A., Planter M., 1998. Stan czystości wybranych jezior Parku Krajobrazowego Pojezierza Iławskiego. Państwowa Inspekcja Ochrony Środowiska, Wojewódzki Inspektorat Ochrony Środowiska w Olsztynie.

GGK [Główny Geodeta Kraju], 2001. Mapa hydrograficzna Polski w skali 1:25 000. Sheet N-34-88-A Iława. Centralny Ośrodek Dokumentacji Geodezyjnej i Kartograficznej, Warszawa.

GGK [Główny Geodeta Kraju], 2010. Mapa hydrograficzna Polski w skali 1:25 000. Sheets: N-34-75-D Susz, N-3476-A Zalewo, N-34-76-C Jerzwałd, N-34-87-B Kisielice. Centralny Ośrodek Dokumentacji Geodezyjnej i Kartograficznej, Warszawa.

GGK [Główny Geodeta Kraju], 2014. Ortofotomapa w barwach rzeczywistych (RGB); rozdzielczość $0,5 \mathrm{~m}$. Centralny Ośrodek Dokumentacji Geodezyjnej i Kartograficznej, Warszawa.

Grandke M., 2009. Zmiany powierzchni jezior Breńskie i Białe-Miałkie (Pojezierze Sławskie) w latach 1778-2008. Studia Limnologica et Telmatologica3(1): 3-24. 
GUGiK [Główny Urząd Geodezji i Kartografii], 1982. Mapa topograficzna Polski w skali 1:25 000. Sheets: 221.24 Zalewo, 221.41 Prabuty, 221.42 Jerzwałd, 221.44 Siemiany, 222.31 Miłomłyn, 222.33 Samborowo, 231.22 Iława. Centralny Ośrodek Dokumentacji Geodezyjnej i Kartograficznej, Warszawa.

Jańczak J. (ed.), 1997. Atlas jezior Polski. T. 2 Jeziora zlewni rzek Przymorza i dorzecza dolnej Wisty. Bogucki Wydawnictwo Naukowe, Poznań

Kalinowska K., 1961. Zanikanie jezior polodowcowych w Polsce. Przeglad Geograficzny 33(3): 511-518.

KDR [Die Karte des Deutschen Reiches] 1893, 1:100 000. 132 Christurg (Dzierzgoń), 165 Dtsch. Eylau (Iława). Berlin. Online: www.landkartenarchiv.de (accessed May 31, 2017).

Kleczewska-Witt E., 1983. Analiza porównawcza zarastania jezior poligonu fotointerpretacyjnego "Mosina". Fotointerpretacja w geografii $\mathrm{VI}(16):$ 74-90.

Kowalczyk P., 1993. Zróżnicowanie zarastania jezior w zlewniach $w$ obrębie wydzielonych pojezierzy. MS, Instytut Geografii UAM, Poznań.

Krąż P., Piasecki A., 2015. Zmiany misy jeziora Bobięcińskiego Wielkiego z wykorzystaniem narzędzi GIS. Wspótczesne problemy i kierunki badawcze w geografii 3: 197-206.

Macioch A., Malmon G., 2010. Funkcje interaktywne współczesnych map elektronicznych. Polski Przegląd Kartograficzny 44(4): 331-353.
Mapster, 2017. Topographische Karte 1:25 000 (Meßtischblatt-Ostdeutschland) /1870-1945/. Online: igrek. amzp.pl (accessed may 31, 2017).

Nowacka A., Ptak M., 2007. Zmiany powierzchni jezior na pojezierzu Wielkopolsko-Kujawskim w XX w. Badania Fizjograficzne nad Polska Zachodnia. Seria A: Geografia Fizyczna 58: 149-157.

Piasecki A., 2013. Zmiany powierzchni jezior Pojezierza Dobrzyńskiego w świetle materiałów kartograficznych. Prace Geograficzne IGGP UJ 132: 39-57.

Ptak M., 2010. Zmiany powierzchni jezior na tle zmian lesistości w środkowym i dolnym dorzeczu Warty od końca XIX wieku. In: Ciupa T., Suligowski R. (eds), Woda w badaniach geograficznych: 151-159.

Ptak M., 2013a. Zmiany powierzchni i batymetrii wybranych jezior pojezierza pomorskiego. Prace Geograficzne 133: 61-76.

Ptak M., 2013b. Lake evolution in the Żnin region in the years 1912-1960 (central Poland). Quaestiones Geographicae 32(1): 21-26.

Urbański J., Kryla-Staszewska L., 2009. Monitoring i modelowanie jezior $w$ systemach geoinformacyjnych. In: Zwoliński Z. (ed.), GIS - woda w środowisku, Bogucki Wydawnictwo Naukowe, Poznań: 121-146. 